Predrag Vuković ${ }^{1}$

Institute of Agricultural Economics,

Belgrade
SCIENTIFIC REVIEW ARTICLE doi:10.5937/ekonomika1804079V

Received: September, 18, 2018 Accepted: October, 18, 2018

\title{
THE FORMATION AND PROMOTION OF RURAL TOURIST PRODUCT IN THE REPUBLIC OF SERBIA ${ }^{2}$
}

\begin{abstract}
Business on tourism market requires perception of the interests of supply and demand at micro and macro level. The tendency is to place the market products on the market that enable the achievement of the business goal and the satisfaction of both sides, supply and. demand. Rural tourism with its specificities, requires a careful approach to tourist demand and its segments, i.e. niches. Consistent implementation of the marketing concept with adequate investments policy and market research, creation and placement of a tourist product is a guarantee of success on the market. Serbia has respectable resources for the development of rural tourism (natural and social). However, in practice, the problem arises in the insufficient recognition of local stakeholders in the ability to put these resources in an adequate manner in the function of tourism development, as well as local communities, more broadly. The aim of the paper work is to present a marketing approach in formation and promotion the rural tourism product, based on the resources the Republic of Serbia has.
\end{abstract}

Key words: tourism, destination, rual areas, segment, promotion, formation

JEL classification: M31, M37, Q13.

\section{ФОРМИРАҢЕ И ПРОМОЦИЈА РУРАЛНОГ ТУРИСТИЧКОГ ПРОИЗОВДА У РЕПУБЛИЦИ СРБИЈИ}

\section{Апстракт}

Пословање на туристичком тржишту захтева периепцију интереса понуде и тражне на микро и на макро нивоу. Тежњ а је да се тржишту пласирају туристички производи који омогућавају остварење ииьь пословања и сатисфакцију обе стране, понуде и тажне. Рурални туризам са својим специфичностима захтева пажљьв приступ туристичкој тражњи и њеним сегментима, односно нишама. Доследна примена маркетинг концепта са адекватним улагањима у истраживање тржишта, креирање и пласман туристичког производа представља

\footnotetext{
${ }^{1}$ predrag_v@iep.bg.ac.rs

${ }^{2}$ Article as invited lecture was presented $10^{\text {th }}$ May 2018, at the "Ninth Tourism Forum" which has been held between $9^{\text {th }}$ to $12^{\text {th }}$ May 2018, in Palić, Subotica, organized by the Tourist Organization of Serbia. Article is part of project III - 46006 „Sustainable agriculture and rural development in the function of accomplishing strategic objectives of the Republic of Serbia in the Danube region", financed by the Ministry of Education, Science and Technological Development of the Republic of Serbia in the period 2011-2018.
} 
гарант успеха. Србија има респектабилне ресурсе за развој руралног туризма (природне и друштвене). Међутим, у пракси проблем настаје јер локални стејкхолдери нису у могућности да препознају могућности да се ти ресурси ставе на адекватан начин у функцију развоја туризма, као и локалних заједница, шире гелдано. Циљ рада је да представи маркетинг приступ у кеирању руралног туристичког производа, полазећи од ресурсних могућности које Република Србија има.

Кључне речи: туризам, дестинација, рурална подручја, сегмент, промоција, формирање

\section{Introduction}

Rural tourism has been developing with different intensity in the Republic of Serbia since the seventies of the twentieth century. Nowadays he has different intensity, forms and character in different parts of Serbia. They are determined by the natural-geographical characteristics of the area, the degree of development of the local economy, the anthropotics heritage and the awareness of the local population about its importance for development of the local communities. (Vuković, P., 2017, p.58.)

Starting from the fact that more than $80 \%$ of the territory of the Republic of Serbia cover of rural areas, according to the 2011 Census, and that $44 \%$ of the total population lives in these areas, the question arises is regarding valorisation of numerous resources (natural and social - anthropogenic) that Serbia possesses these areas. In order to realize this, it is necessary to create a large number of tourist products. Success will be guaranteed if there is a marketing and managerial approach. This can only be achieved through the education of all levels of management involved in the process of managing rural tourism products.

\section{Concept of rural tourist product}

The issue of defining a tourism product is complex, because it can be a single service for a company (eg hotel accommodation), a set of "packaged" services (for example, a lump sum trip) or even a whole tourist destination. For this reason, there is a large number of definitions of a tourist product in the literature whose content difference is based on different approaches to defining this term. (Zečević, B. 2007, p.118).

Bakić, O. (2005, p.128) carries out the classification of all theoretical views expressed when defining a tourism product in four basic groups:

1) those who consider the tourist product as a "mixture" (amalgam) of various elements and its constituent parts.

2) the attitudes that the product observe from the aspect of individual offerers (hotel companies, utility companies, travel agencies, etc.).

3) those which observed the product as original compound and derivative elements of tourist attractions.

4) attitudes that consider a tourist product as partial and as an integrated product.

Bearing in mind the complexity of the problem McCarthy, J. (1978, pp. 237-240), introduces the concept of the so-called. a total product, which is much more than a physical 
product, because it also implies its functional and esthetic characteristics. The complete product, in addition, does not necessarily include a physical or material product, as in the case of a service.

Kotler at al. (2006, p. 304) have a very wide approach in defining a tourist product. They emphasize that under the product can be considered all that can be offered to the market, in order to attract attention, encourage purchasing, use and consumption, so that the needs and desires can be met. Products include physical objects, services, places, organizations and ideas. This definition, according to them, is the planned part of the product that the company offers. A tourist product also means an unplanned part and includes all the benefits and "surprises" (pleasant and unpleasant) that tourists receive while staying in a particular destination.

A certain number of authors point out that the tourist destination is one, but also many products. (Manente, M. and Mangeti, V., 2006, p.76; Buhallis, D., 2000, p.97; Seaton 1996, pp. 350-351, etc.)

According to the Law on Tourism (Official Gazette of the Republic of Serbia, No. 36/2009, 88/2010, 99/2011 - other Law, 93/2012 and 84/2015): "tourism product is a set of interdependent elements that are organizes the practice as a special value chain, which consists of material products and services, natural values and cultural assets, tourist attractions, tourist suprastructure and tourist infrastructure.

Bearing in mind the definition of rural tourism provided by numerous international organizations that follow its development, character and dynamics such as:

- OECD document „Tourism Strategies and Rural Development" (OECD 1994, p. 14 -16.);

- $\quad$ EuroGites, (European Federation of Rural Tourism 2005 at a conference in Yalta in Ukraine);

- UN FAO document „The Scope of Organic Agriculture, Sustainable Forest Management and Ecoforestry in Protected Area Management" (UN FAO, 2004, pp. 16-17), as well as the fact that the rural area represents the basis on which rural tourism is based and on which its development is based, which is clearly emphasized in the Encyclopaedia of Tourism (2005), it can be concluded that the rural tourism product represents all the things that are defined according to the applicable "Law on Tourism" (Official Gazette of the Republic of Serbia, No. 36/2009, 88/2010, 99/2011 - Law on the Law, $93 / 2012$ and 84/2015) in defining a tourist product with a clear indication that the characteristics are related for the rural area and its specificities.

The first document that explores the phenomenon of rural tourism in a comprehensive way was "Tourism Strategies and Rural Development", (OECD, 1994). The author of this document Lane B. says that the basic characteristics of rural tourism are related to:

1) Located in rural areas;

2) Functionally rural - built upon the rural world's special features;

3) Rural in scale;

4) Traditional in character, growing slowly and organically, and connected with local families;

5) Sustainable - in the sense that its development should help sustain the special rural character of an area, and in the sense that its development should be 
sustainable in its use of resources. Rural tourism should be seen as a potential tool for conservation and sustainability, rather than as an urbanizing and development tool;

6) Of many different kinds, representing the complex pattern of rural environment, economy and history.

The same document emphasizes the factors one must consider when determining rural tourism (type of vacation, intensity of vacation use, location, management, style, degree of integration with the community), (OECD, 1994).

Kotler at al. (2006, p.399) define the value delivered to the customer as a consumer's assessment of the overall product capability to meet its needs. They also point out that the difference between the total value for the client and the total cost of the marketing offer is the earnings for the client or the value delivered to the client. The formation of a unified tourism product by consumers directly depends on the availability of all elements of the tourist offer.

The World Tourism Organization document "A Practical Guide to Tourism Destination Management" (UNWTO, 2007, p.1), presented the basic elements of tourist destination supply: attractions, private facilities and services, availability, human resources, image and character, price. These views were later accepted by other authors in literature (such as, V.T.C. Middleton, Fyall, A., Morgan, M., Ranchold A., 2009; Kotler, P., Bowen, J., Makens, J. 2006, etc.).

Concept is based on marketing view on tourism as synergic economic acitivity. Tourism include material and non material elements in tourist supply . i.e. tourist product include mix of product and services. Total tourist product include large scale of material and non-material usefulness which consumer/tourist/visitors buy.

Numerous autors (Kotler at. al. 2006, p.305., Zečević, B. 2007, p. 121; Gonroos C., 1987, p.83. etc.) classify four level of tourist product:

1) The basic product are what tourists actually buys.

2) The expected product represents services or goods that must be present (they are implied) so that tourists can consume the basic product.

3) An additional product provides added value to the basic product and helps it to be different from the competitor. Often they are confronted with the expected and additional products. This stems from the fact that what the expected products represent to a single market segment can represent additional products (content) to another. For example, if a family holiday does not require catering in an accommodation, business travelers staying in it are expected.

4) The expanded product includes all the contents that come to meet tourists in order to raise the level of quality of the basic product, they are combined with them. They mean availability, atmosphere, customer interaction with the service organization, customer involvement and their interaction.

Following this logic it could be given a more detailed description of rural tourist product (table 1.) 
Table 1. - Four level of destination tourist product

\begin{tabular}{|l|ll|}
\hline \multicolumn{1}{|c|}{ Level of product } & & \multicolumn{1}{c|}{ Example } \\
\hline The basic product & - & Attraction and recreation. \\
& - & Hospitality services of accommodation and food \\
\hline \multirow{4}{*}{ The expected product } & - & Ecological preservation of the rural area \\
& - & Tidiness of the rural household \\
& - & Available climate conditions in the destination \\
& - & Traffic connections \\
\hline \multirow{3}{*}{ An additional product } & - & Tourist info centers \\
& - & Conditions for fun \\
& - & Conditions for shopping / shopping \\
\hline \multirow{3}{*}{ The expanded product } & - & Animation of tourists, etc. \\
& - & Shysical segregation of segments of tourists \\
& & (eg young people from families with children, etc.) \\
\hline
\end{tabular}

Source: Addopted according to Zečević, B. (2007), Marketing turističkih destinacija - uloga informacione tehnologije, p.121.

\section{Formation of the rural tourist product}

The "Master Plan for the Sustainable Development of Rural Tourism" (2011, p. 91) emphasizes that the rural tourism product is the concept of an integrated rural experience based on the interaction between rural accommodation, built facilities and rural activities (Figure 1.)

Figure 1. Process of formatting rural tourist product

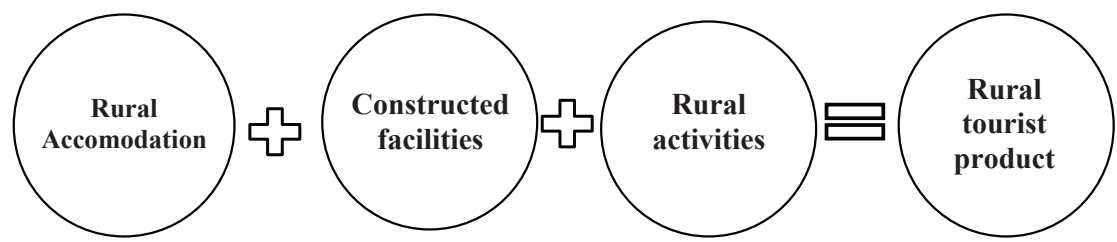

Source: The Master plan of sutainable development or rural tourism in Serbia, 2011, UNDP, p. 91.

The Strategy for Rural Tourism Experiencing is suggested on the following way:

- development of an integrated and holistic experience of Serbian rural tourism, focusing on the development of rural activities and rural accommodation, with the simultaneous focus on the integration of these three components.

- $\quad$ support the development of an integrated strategy for the experience of rural tourism by identifying ways in which different elements (activities and accommodation) can be complemented. 
- building centers for activities that will support the development, commercialization and achivement of rural activities at central points across the territory.

- involvement of local stakeholders in the development of the rural tourism experience. They should be involved in the development of rural activities, rural accommodation and local rural tourism facilities.

- $\quad$ investing a special and focused effort to reduce the differences in rural tourism seen in the qualitative analysis of the tourism sector (in the Diagnostic Report), through the development of products and activities involving local communities. This is especially important for the development of products and services that include agricultural products in the tourism sector.

\section{a) Rural accomodation}

In the Republic of Serbia unfortunentlly there is no uniqe base of rural tourist accommodation facilities. Today there are some iniciatives which comes from Tourist organization of Serbia and some branches tourist associtations.

One of bigist assoctiations of rural tourism in Serbia is "The Rural Tourism of Serbia". This national association established nine associations in 2002. Today association is counting more than 500 members. In 2004, the association has set up a presentation www.selo.co.yu which is designed as a database of the total rural tourist accommodation deals. In 2005, it realized project "Promotion of rural tourism in Serbia," which includes all municipalities and tourism organizations of municipalities and cities that have a rural tourist offer. During the years, the Internet site has recorded continuous rise in the number of visitors, and in 2006 over 200 rural households that are located in the database of the site received $90 \%$ of the guests particularly through the website. Thanks to the results of the Internet website, the National Association "Rural tourism of Serbia" is an active member and representative of Serbia in the "European Federation of Rural Tourism - EUROGITES" (Vuković, P. at al. 2016, p. 271.).

It is important to highlight that UNWTO (2007) set private and public facilities and services as a secnod important subject of tourist destination supply who attract visitors to come and stay in destination. It points out that there is a wide scale of various facilities and services that support to come and stay of tourists in the destination, which includes infrastructure (public services, public transport and roads) and direct services to visitors (accommodation, information for guests, relaxation facilities, guides, catering and sales facilities).

UNWTO and OECD publications (2012), as well as the Statistical Office of the Republic of Serbia (Monthly Statistical Bulletin 01/2018), group receptive capacities according to the appropriate methodology in a similar manner. It is common for receptive capacities to be classified into:

- basic receptive capacities, under which we mean facilities for tourist accommodation and facilities for food and drink (hospitality facilities),

- $\quad$ supplementary receptive capacities involving various types of facilities in which food, beverages, consumer goods shops, various types of services, food and recreation facilities for tourists, etc, are sold, etc.

- Complementary receptive capacities. 


\section{b) Constructed (built) facilities}

In rural areas, the built-in attractions include rural settlements, rural farms, planning and urban organization of facilities in a rural settlement, rural road network, shape, size and number of agricultural parcels, types and layouts of trees and other green areas (Ružić, P., 2009).

\section{c) Rural Activities}

It is considered that the opportunity to deal with non-pension activities in rural areas is the key to gaining competitive advantage on the market nowadays.

Roberts L, and Hall D., (2003) summarized the views of Thibal S., (1988) and Lane B., (1994, p. 16), and made a list of off-board tourist activities that can take place in rural tourist destinations (Table 3).

Table 3. Non-pansion tourist activities in rural tourist destinations

\begin{tabular}{|c|c|c|}
\hline No. & Type of activity & Activity specification \\
\hline 1. & Touring & $\begin{array}{l}\text { - Hiking (footpaths, fitness trails, nature parks), } \\
\text { - } \text { Horse-riding, } \\
\text { - } \text { Motorized touring, } \\
\text { - } \text { Small town/village touring, } \\
\text { - } \text { Advanture holidays/ village touring, } \\
\text { - } \text { Cycling, } \\
\text { - } \text { Cross-country skiing, } \\
\text { - } \text { Donky riding, } \\
\text { - } \quad \text { Touring in gypsy caravans, wagons } \\
\end{array}$ \\
\hline 2. & Water-related activities & 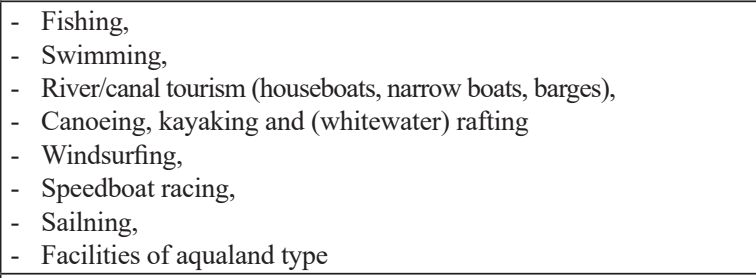 \\
\hline 3. & Air related activities & $\begin{array}{ll}\text { - } & \text { Light aircraft, } \\
\text { - } & \text { Hang-gliding and micro-light aircraft, } \\
\text { - } & \text { Hot air ballons, } \\
\text { - } & \text { Paragliding. } \\
\end{array}$ \\
\hline 4. & Sport activities & $\begin{array}{l}\text { a) Reguiring natural settings: potholing, rock climbing, orienteering. } \\
\text { b) Requiring modified/constructed settings: tennis, golf, hunting, } \\
\text { low-intensity downhill skiing. }\end{array}$ \\
\hline 5. & $\begin{array}{l}\text { Cultural } \\
\text { activities }\end{array}$ & $\begin{array}{l}\text { - } \text { Archaelogy, } \\
\text { - } \text { Restoration sites, } \\
\text { - } \text { Rural heritage studies, } \\
\text { - } \text { Museums, } \\
\text { - } \text { Local industrial, agricultural or craft enterprises, } \\
\text { - } \text { Courses in crafts, } \\
\text { - } \text { Artistic expression workshops, } \\
\text { - } \text { Folk groups, } \\
\text { - } \text { Cultural, gastronomic and other routes. }\end{array}$ \\
\hline
\end{tabular}




\begin{tabular}{|c|c|l|}
\hline 6. & Health-related activities & $\begin{array}{l}- \text { Fitness training, } \\
- \text { Spa and health resorts, } \\
- \text { Assault courses. }\end{array}$ \\
\hline 7. & $\begin{array}{c}\text { Passive } \\
\text { activities }\end{array}$ & $\begin{array}{l}- \text { Relaxation holidays in a rural milieu, } \\
- \text { Nature study in outdoor settings, including birdwatching, } \\
\text { photography. } \\
\text { Landscape appreciation. }\end{array}$ \\
\hline $\mathbf{8 .}$ & Hallmark activities & $\begin{array}{l}- \text { Rural sporting festivals, } \\
- \text { Agricultural shows }\end{array}$ \\
\hline $\mathbf{9 .}$ & $\begin{array}{c}\text { Rural business related } \\
\text { activities }\end{array}$ & $\begin{array}{l}- \text { Small scale conventions/conferences; } \\
- \text { Incentive tourism short-breaks, }\end{array}$ \\
\hline
\end{tabular}

Source: Roberts L, and Hall D., (2003): "Rural Tourism and Recreation: principles to practice”, Leisure and Tourism Management Department, The Scottish Agriculture College, Auchincruive, Ayr, UK, CABI Publishing, p. 2.

\section{Tourist product life cycle}

The task of management is to manage products from the moment the idea arises, until the moment of making a decision on its "extinguishment", a leave of absence. In order to monitor product development and, generally speaking, its "life", a product life cycle is used as an important analytical tool in marketing, or a shortened PLC - "product life cycle". The idea that went into the development of the concept is that nothing, and even the product is not eternal.

There is a great consensus of the author in marketing literature that the product is moving through four phases of the life cycle: introduction, growth, maturity and decline.

In order to better understand marketing goals and strategies throughout the product life cycle, we can best use the tables made by Jobber and Fahy (2006, p.160.).

Table 3. - Marketing goals and strategies throughout the product life cycle (PLC)

\begin{tabular}{|l|c|c|c|c|}
\cline { 2 - 5 } \multicolumn{1}{c|}{} & Introduction & Growth & Maturity & Decline \\
\hline $\begin{array}{l}\text { Strategic } \\
\text { marketing }\end{array}$ & Build up & Build up & $\begin{array}{c}\text { Harvest } / \\
\text { pulling out } \\
\text { money }\end{array}$ \\
\hline Strategic focus & $\begin{array}{c}\text { Market s } \\
\text { pred }\end{array}$ & Penetration & $\begin{array}{c}\text { Protect } \\
\text { share }\end{array}$ & Productivity \\
\hline $\begin{array}{l}\text { The brand } \\
\text { goal }\end{array}$ & $\begin{array}{c}\text { Product awareness } \\
\text { / test }\end{array}$ & $\begin{array}{c}\text { Brend } \\
\text { Preference } \\
\text { the brand }\end{array}$ & Brend exploatation \\
\hline Products & Basic & Differentiated & Differentiated & Rationalized \\
\hline Promotion & $\begin{array}{c}\text { Creating awareness / } \\
\text { provoking a test }\end{array}$ & $\begin{array}{l}\text { Creating awareness / } \\
\text { trial } \\
\text { purchases }\end{array}$ & $\begin{array}{l}\text { Maintenance } \\
\text { awareness / } \\
\text { repeated } \\
\text { purchase }\end{array}$ & $\begin{array}{c}\text { Stop/ } \\
\text { Eliminate }\end{array}$ \\
\hline Price & High & Lower & Lowest & Growing \\
\hline Sale & Weaker & Wider & Intensive & Selective \\
\hline
\end{tabular}

Source: Jobber D \& Fahy J., (2006): ,,Fundations of Marketing“, McGraw-Hill Education (UK) Limited, p.160. 


\section{Promotion of the rural tourist product of Serbia}

A destination promotion strategy made up of a number of elements has the basic task of informing and encouraging tourist demand for staying in the destination (Bakić, O., 2005, p. 132-133.)

A promotional mix could be defined as a mix of propaganda, sales promotion, public relations, personal sales, and publicity. Optimal combination of these elements should also give optimal results. This is why this issue is of strategic importance for the destination, and it is mainly visited by the Tourist Organization of Serbia (TOS) in Serbia.

Mil C., (1990) state that a phase in the process of forming a promotional mix are following:

a) Determining priority markets and segments.

b) Precise the targets of the promotional mix depending on the market.

c) Developing an appropriate offer

d) Selection of promotional mix instruments

e) Providing financial resources for promotional activities.

f) Control of the implementation and correction of promotional activities.

Some of the funds available for promotion are:

1. Graphic resources: "tourist informer", tourist map, general prospectus of the city, pocket format informers, luxury publications with detailed information about the city offer for specific occasions (congresses, fairs ... etc.).

2. Audio-visual means: spots, tourist films, video tapes, CD-ROM of appropriate content, video-text that allows two-way communication, "holograph" as a combination of Smart building and a total combination of everyday activities that tourists have at the destination of the so- "virtual reality".

3. Website of the city - some of the web sites where the destination can be promoting.

4. Tourist information centers intended for visitors who are in the Republic or outside the country. An important role here is the choice of location where the center opens but primarily targeted market segments, or target consumer groups.

\section{Conclusion}

Serbia has respectable resources for development of rural tourism. The attitude is based on the rich natural and social (anthropogenic) resources which are located in the rural areas. Creativity in making rural tourism products should enrich the tourist supply of Serbia. All comparative advantages that certain destinations have (natural and social - anthropogenous) should be used in the formation rural tourist product. In this way, the assumption of their future competitiveness is created.

One of the basic characteristics of the tourist offer is its fixedness, while on the other side demand has an elastic character. For this reason, when forming a product, it should be ensured that the supply is such that it can easily be adapted to any eventual changes in the tourist market. In this way, the lifetime of a tourist product is prolonged. 
Rural tourism is in the initial level of development in Serbia. In order to allow for its systematic development to achieve the best results, set its balanced development, to stop numerous negative processes that burden the living of population in rural areas (unemployment, accelerated aging of the rural population, migration of the population into large urban cities, decline in macroeconomic indicators, etc.) it is very important that all stakeholders must be educate on the way they can form rural tourist products. The expectations are that rural tourism will enable the "development wheel" of rural areas to be launched. In the organization of educational activities, local authorities, regional chambers of commerce, the Tourist Organization of Serbia, local associations and associations of farmers, advisory services, etc. should play an important role.

Bearing in mind the synergistic character of tourism (as a business, tourism links a large number of economic and non-economic activities) and its positive multiplier effects on the area (destination) in which it is developing, it is important at the very beginning of it development to start it in a systemic way. This practically means that all innovations in the knowledge of the countries that have achieved the best results in rural tourism development should be used (such as Austria, Italy, Switzerland, Germany, France, etc.), as well as from the fields of marketing and management in the development of rural tourist destinations. Also, the promotion of a tourist product may be one of the crucial activities to attract demand. Considering the spatial distance of rural areas from urban city centers, it is necessary to use all available promotional mix instruments. The advancement of information and communication technologies is certainly in favor of promotional activities. It allows to overcome "GAP" in the spatial distance of rural from urban city centers. In addition to strengthening the promotion activities in addition to the Tourist Organization of Serbia, which according to the Law of tourism is obliged to perform promotional activities, other factors should be included in the promotional activities. This applies to the public and private sectors - its stakeholders.

If this approach were to be adopted, the basis for the successful development of rural tourism would be created.

\section{References}

“A Practical Guide to Tourism Destination Management”, UNWTO, 2007, Madrid.

Bakić O., (2005): „Marketing menadžment turističke destinacije“, Čigoja štampa, Beograd.

Boyd W. H. \& Walker Jr. (1990): “Marketing Management, a Strategic Approach", Irwin, Homewood, Ill.

Buhallis, D., (2000): „Marketing the competitive destination of the future“, Tourism Management 21, (2000), pp. 97-116.

Enciclopedia of Tourism (2005), published by Routledge, 2 Park Square, Milton Park, Abingdon, Oxon, OX.

Gonroos C., (1987): "Developing the Service Offering - A Source of Competitive Advantage", in Add Value to Your Service, AMA - American Marketing Association, Chicago, 
Jobber D., \& Fahy J., (2006): „Fundations of Marketing“, McGraw-Hill Education (UK) Limited

Kotler, P., Bowen, J., Makens, J. (2006): „Marketing u ugostiteljstvu, hotelijerstvu i turizmu“, Mate, Zagreb

Lane B., (1994): "What is Rural Tourism", Journal of Sustainable Tourism, No. 1-2., Vol. 2., pp. 7-21.

McCarty J., (1978): „Basic Marketing: A Managerial Approach“, Richard D. Irwin Inc., Homewood, p. 237-240.

Manente, M. and Mangeti, V., (2006): „Organizations and Participants in Destination Management", Tourism Futures, Tourism Business Frontiers: Consumers, Products and Industry, Buhalis, D., Costa, C., ed., Butterworth-Heinemann, Oxford, p.76.

Middleton, V.T.C., Fyall, A., Morgan, M., Ranchold A. (2009), Marketing in Travel and Tourism, Butterworth-Heinemann, Oxford, 2009;

Mil C., (1990), Tourism - The International Business, Prentice Hall international Inc., Englewood, Cliffs, New Jersy.

Monthly Statistical Bulletin 01/2018, Statistical Office of the Republic of Serbia, link: http://arhiva.stat.gov.rs/WebSite/repository/documents/00/02/81/30/MSB-012018.pdf (accessed 01.09.2018)

OECD (1994): “Tourism Strategies and Rural Development”, Appendix A., p. 47-50, OCDE/GD (94) 49, web link: http://www.oecd.org/dataoecd/31/27/2755218.pdf (accessed: 26.08. 2018).

OECD (2012): „Torurism Trends and Policies 2012“, p. 94, web. site: http://www. keepeek.com/Digital-Asset-Management/oecd/industry-and-services/oecdtourism-trends-and-policies-2012_tour-2012-en (accessed: 21.08.2018.)

Republički zavod za statistku, Mesečni statistikčki bilten, 01/2018.

Roberts L, and Hall D., (2003): "Rural Tourism and Recreation: principles to practice", Leisure and Tourism Management Department, The Scottish Agriculture College, Auchincruive, Ayr, UK, CABI Publishing.

Ružić, P., (2009,): „Ruralni turizam“, Institut za poljoprivredu i turizam, Poreč.

Seaton, A. V. (1996): “Destination Marketing”, p. 350-356, in A. V. Seaton and M. M. Bennett, The Marketing of Tourism Products: Concepts, Issues and Cases, International Thompshon Bussines Press, London.

Scialabba, N. E., and Williamson, D., (2004): „The Scope of Organic Agriculture, Sustainable Forest Management and Ecoforestry in Protected Area Management", working paper No. 18, p. 16-17, UNFAO - Food and Agriculture Organization of the United Nations, Rome, 2004. web site: ftp://ftp.fao.org/docrep/fao/007/ y5558e/y5558e00.pdf (accessed: 26.08. 2018)

Seaton, A. V. (1996), Destination Marketing, pp. 350-376, in A.V. Seaton and M. M. Bennett, The Marketing of Tourism Products: Concepts, Issues and Cases, International Thomson Bussines Press, London. 
The Master plan of sutainable development or rural tourism in Serbia, 2011, UNDP, MDGIF.

Thibal S., (1988): "Rural Tourism in Europe", Council of Europe, Strasburg.

„Tourism Strategies and Rural Development”, OECD, 1994, web. site: http://www. oecd.org/dataoecd/31/27/2755218.pdf (на дан 25.08. 2018 год.)

Vuković, P.,(2017): „Character and dynamics of development rural tourism in the Republic of Serbia“, journal: Ekonomika, No. 4. Vol. 63, pp. 53 - 60.

Vuković, P., Popović, V. and Arsić. S. (2016): „State and Condition for implementing ICT in Roural Touirsm in the Republic of Serbia“, Thematic Proceedings: „Emerging Technologies and the development of agriculture", EAAE (European Association of Agricultural Economist) seminar, August 30th - September 1st, 2016 Novi Sad Serbia, Published by Serbian Association of Agricultural Economist, Faculty of Economics, Subotica, Institute of Agricultural Economics, Belgrade, pp. 257-275.

Zakonu o turizmu (Sl. Gl. R. Srbije, br. 36/2009, 88/2010, 99/2011 - dr. zakon, 93/2012 i $84 / 2015$ )

Zečević. B., (2007): Marketing turističkih destinacija - uloga informacione tehnologije, Jugo knjiga komerc, Biograf, Zemun, Beograd. 